\title{
PEMANFAATAN NILAI PEDULI SOSIAL CERITA RAKYAT DI KABUPATEN PURBALINGGA SEBAGAI PENGEMBANGAN PENDIDIKAN KARAKTER DALAM PEMBELAJARAN BAHASA INDONESIA
}

\author{
Wiwit Puji Amalia,Sumarwati, Budhi Setiawan \\ Universitas Sebelas Maret \\ Surel:wiwitamalia@student.uns.ac.id
}

\begin{abstract}
Abstrak: Penelitian ini merupakan penelitian deskriptif kualitatif yang bertujuan untuk (1) mendeskripsikan dan menjelaskan struktur cerita rakyat Kabupaten Purbalingga, (2) mendeskripsikan dan menjelaskan nilai-nilai peduli sosial yang terdapat dalam cerita rakyat Kabupaten Purbalingga, dan (3) relevansi cerita rakyat sebagai pengembangan pendidikan karakter dan bahan ajar di Sekolah Menengah Pertama. Data dan informasi dikumpulkan melalui informan dan dokumen. Pengumpulan data dilakukan melalui observasi, rekaman, wawancara, dan analisis dokumen. Sampel penelitian ditentukan dengan teknik purposive sampling. Validasi data dilakukan dengan triangulasi data. Hasil penelitian ini adalahmenemukan : (1) struktur cerita rakyat Kabupaten Purbalingga, (2) nilai-nilai peduli sosial yang terdapat dalam cerita rakyat Kabupaten Purbalingga, (3) relevansi cerita rakyat sebagai pengembangan pendidikan karakter dan bahan ajar di Sekolah Menengah Pertama.
\end{abstract}

Kata Kunci: cerita rakyat, nilai peduli sosial, pendidikan karakter

\section{UTILIZATION OF SOCIAL CARE VALUE OF FOLKLORE IN PURBALINGGA DISTRICT AS CHARACTER EDUCATION DEVELOPMENT IN INDONESIAN LANGUAGE LEARNING}

\begin{abstract}
This research is a qualitative descriptive research aims to (1) describe and explain the structure of folklore of Purbalingga District, (2) to describe and explain the social care values contained in Purbalingga District folklore, (3) describe and explain the relevance of folklore as the character buildingand teaching material in Junior High School. Data and information are collected through informants and documents. Data collection is done through observation, recording, interview, and document analysis. Research sample is determined by purposive sampling technique. Validation of data is done by triangulation. The results of this research are: (1) the structure of folklore Purbalingga District, (2) social caring values contained in Purbalingga District folklore, (3) relevance of folklore as the character building and teaching material in Junior High School.
\end{abstract}

Keywords: folklore, social care value, character building

\section{PENDAHULUAN}

Pendidikan mempunyai peran yang penting dalam pengembangan diri siswa. Pendidikan dituntut untuk tidak hanya mencerdaskan, tetapi juga membangun karakter siswa agar siswa memiliki kepribadian yang baik. Karakter adalah bentuk watak, tabiat, akhlak yang melekat pada pribadi seseorang yang terbentuk dari hasil internalisasi yang digunakan sebagai landasan untuk berpikir dan berperilaku sehingga menimbulkan suatu ciri khas pada individu tersebut (Maunah, 2015:7). Karakter individu akan berkembang dengan baik apabila mendapatkan penguatan yang tepat berupa pendidikan yang di dalamnya memuat nilai-nilai pendidikan karakter. Pendidikan karakter mempunyai tujuan penanaman nilai dalam diri siswa dan pembaruan tata kehidupan bersama yang lebih menghargai kebebasan individu. Selain itu, pendidikan karakter bertujuan untuk meningkatkan mutu penyelenggaraan dan hasil pendidikan di 
sekolah yang mengarah pada pencapaian pembentukan karakter dan akhlak mulai siswa secara utuh, terpadu, dan seimbang sesuai dengan standar kompetensi lulusan (Wibowo, 2012:25).

Sebagai bangsa dengan berbagai macam kebudayaan, Indonesia memiliki banyak tradisi dan nilai-nilai kearifan lokal yang perlu dilestarikan dan dikembangkan agar karakter dan ciri khas manusia Indonesia dengan berbagai nilai budayanya tidak hilang begitu saja seiring pengaruhpengaruh negatif dari budaya materialisme dan individualisme. Banyak tradisi dan nilai-nilai lokal justru menjadi kekuatan yang sangat penting dalam kerangka ketahanan kehidupan berbangsa dan bernegara di era globalisasi. Pada penelitian yang dilakukan oleh Davidson, dkk (2007:4) ditemukan adanya peran karakter dalam semua jenis prestasi sekolah, baik kurikuler maupun nonkurikuler. Hasil penelitian tersebut disampaikan bahwa karakter terdiri dari dua bagian besar yaitu karakter kinerja (performance character) dan karakter moral (moral character). Karakter kinerja terdiri dari semua nilai yang membuat seseorang mampu mencapai aktualisasi potensi yang sangat tinggi dalam lingkungan kinerjanya (di kelas atau tempat kerjanya). Hal ini menunjukkan bahwa peran pengembangan pendidikan karakter di sekolah menjadi salah satu faktor yang digunakan untuk menguatkan dan membentuk kepribadian siswa. Pengembangan pendidikan karakter diterapkan dengan cara menyisipkan nilainilai luhur ke dalam pembelajaran Bahasa Indonesia termasuk salah satunya merupakan nilai peduli sosial.

Pengaruh budaya barat yang bersifat immaterial dan cenderung berseberangan dengan budaya timur mengakibatkan norma-norma dan tata nilai kepedulian yang semakin berkurang. Masyarakat yang kehilangan rasa kepedulian akan menjadi tidak peka terhadap lingkungan sosialnya, dan dapat menghasilkan sistem sosial yang apatis. Pendapat lain dikemukakan oleh
Soenarko (2015:23 ) yang menyatakan bahwatingkat sosialisasi individu yang rendah disebabkan oleh kegagalan pada salah satu proses sosialisasi. Tanpa disadari mereka lupa dan tidak menghiraukan lingkungan masyarakat sekitar,sehingga rasa peduli terhadap lingkungan sekitar kalah oleh sikap individualisme yang terbentuk dari berkembang pesatnya kemajuan teknologi dan melunturkan nilai-nilai kebudayaan yang ada.

Menyisipkan nilai-nilai pendidikan karakter ke dalam pembelajaran Bahasa Indonesia masih menjadi hal yang sulit dilakukan karena siswa masih belum terbiasa mengamalkan nilai-nilai tersebut dalam kehidupan sehari-hari. Diperlukan adanya kreativitas dan inovasi untuk mengintegrasikan nilai-nilai pendidikan karakter yang dijadikan materi atau sumber pendidikan. Dalam penelitian yang dilakukan oleh Hajaroh, dkk (2013) ditemukan beberapa hal, di antaranya penerapan nilai-nilai pendidikan karakter yang diimplementasikan di sekolah dapat dilaksanakan dengan mengadopsi sebagian dari nilai-nilai budaya lokal sebagai bahan ajar pendidikan karakter. Pembelajaran yang telah direncanakan tidak hanya membekali siswa dengan pandangan terpadu mengenai pengetahuan umum, tetapi juga memotivasi dan mengembangkan kekuatan siswa untuk memahami pentingnya memiliki kepribadian yang baik.

Dalam penelitian ini, peneliti tertarik untuk meneliti nilai peduli sosial dalam cerita rakyat yang terdapat di daerah Purbalingga yang disisipkan dalam pembelajaran Bahasa Indonesia sebagai pembangun karakter siswa. Harapan lebih lanjut adalah agar kebudayaan-kebudayaan daerah tersebut lebih dikenal oleh masyarakat setempat pada khususnya dan masyarakat luas. Dengan kata lain, penelitian ini merupakan salah satu upaya menjaga kebudayaan daerah setempat agar tidak hilang tergerus zaman dan menjadi penambah wawasan bagi pembaca maupun 
siswa agar dijadikan pedoman dalam menjalani kehidupan. Selain itu, penelitian ini diharapkan bisa dimanfaatkan sebagai alternatif bahan ajar Bahasa Indonesia khususnya di sekolah, sekaligus sebagai pengembangan karakter yang mendukung kepribadian siswa.

\section{METODE PENELITIAN}

Metode yang digunakan dalam penelitian ini adalah metode penelitian deskriptif dengan pendekatan kualitatif. Data yang diambil dalam penelitian ini adalah unsur intrinsik dan nilai peduli sosial lima cerita rakyat Kabupaten Purbalingga yaitu cerita rakyat Asal Usul Purbalingga, Asal Usul Desa Selakambang, Asal Usul Desa Siwarak, Legenda Kerajaan Jambu Karang, dan Legenda Pedukuhan Cibuek. Dari hasil analisis tersebut, nilai peduli sosial diterapkan dalam pembelajaran Bahasa Indonesia di kelas VIIB SMP Negeri 2 Purbalingga KD 3.4 dan 4.4 pada materi fabel dan puisi rakyat.

Teknik pengumpulan data yang digunakan yaitu teknik observasi, wawancara, dan analisis dokumen. Validitas data yang digunakan adalah triangulasi data. Teknik analisis data menggunakan model analisis interaktif yang terdiri dari pengumpulan data, kegiatan reduksi data, penyajian data dan penarikan kesimpulan.

\section{HASIL DAN PEMBAHASAN Kabupaten Purbalingga} Unsur Intrinsik Cerita Rakyat

Cerita rakyat yang berkembang di masyarakat memiliki unsur pembangun yang mendukung terjadinya peristiwa dan alur yang terjadi. Cerita rakyat Kabupaten Purbalingga juga didukung oleh unsur struktur cerita yang meliputi unsur intrinsik dan nilai-nilai yang terkandung di dalamnya atau biasa disebut dengan unsur ektrinsik. Unsur instrinsik yang menjadi pelengkap dan pendukung cerita rakyat. Unsur intrinsik merupakan unsur yang menyusun sebuah karya sastra seperti, tema, tokoh, alur, latar atau setting, dan amanat atau pusat pengisahan. Adapun unsur ekstrinsik adalah unsur penyusun karya sastra dari luar yang menyangkut aspek sosiologi, psikologi, dan lain-lain yang menyangkut berbagai macam nilainilai pendukung unsur intrinsik (Nurgiyantoro, 2007:147). Struktur cerita rakyat Kabupaten Purbalingga didukung oleh unsur intrinsik yang mendukung cerita rakyat yaitu sebagai berikut ini.

\section{Tema Cerita Rakyat}

Tema adalah persoalan yang menduduki tempat utama dalam karya sastra. Tema secara garis besar merupakan gagasan utama, gagasan sentral, atau pikiran pokok. Lebih lanjut dipaparkan bahwa karya sastra yang tidak memuat tema yang mengandung unsur moral merupakan karya sastra yang kurang memiliki manfaat untuk khalayak (Teeuw, 2003:34). Dari pemamparan di atas dapat diartikan bahwa tema merupakan gambaran umum dari suatu karya sastra yang dipaparkan secara tersirat melalui kejadian atau peristiwa yang ada dalam karya sastra. Dari kelima cerita rakyat Kabupaten Purbalingga secara garis besar mengangkat tema tentang kepahlawanan atau patriotisme yang ditunjukkan oleh tokoh-tokoh yang berperan dalam setiap cerita rakyat.

\section{Tokoh dan Penokohan}

Tokoh adalah pelaku yang menjadi penggerak dalam suatu karya sastra. Cerita rakyat selalu mempunyai tokoh untuk menghidupkan alur. Dalam suatu cerita rakyat biasanya terdapat beberapa tokoh, tetapi hanya ada 1 tokoh yang mendominasi dan menjadi peranan penting dalam suatu cerita rakyat. Terdapat 2 jenis tokoh dalam suatu karya sastra yaitu tokoh datar dan tokoh bulat. Tokoh datar adalah tokoh yang hanya menunjukkan satu segi saja, misalnya baik atau buruk saja dari awal cerita sampai akhir cerita. Tokoh juga dibagi menjadi tokoh antagonis dan tokoh 
protagonis yang merupakan sifat dan kepribadian tokoh dalam karya sastra.

Dalam penelitian ini, pengertian tokoh dan penokohan merujuk pada pendapat Nurgiyantoro (2007:165) yang menyatakan bahwa istilah tokoh menunjuk pada orangnya atau pelaku cerita, sedangkan penokohan merupakan pelukisan gambaran yang jelas tentang seseorang yang ditampilkan dalam karya sastra. Tokoh yang terdapat dalam lima cerita rakyat Kabupaten Purbalingga diceritakan memiliki suatu kekuatan dan kebijaksanaan. Tokoh digambarkan secara singkat dan terdapat satu tokoh yang lebih mendominasi dari tokoh-tokoh lain dalam cerita.

\section{Alur}

Alur disebut juga plot yaitu rangkaian peristiwa yang memiliki hubungan sebab akibat sehingga menjadi satu kesatuan yang utuh (Hutomo, 1991:23). Alur terbagi atas beberapa bagian. Bagian awal adalah bagian pengenalan tokoh-tokoh dalam cerita, tikaian adalah konflik yang terjadi diantara tokoh-tokoh dalam cerita, puncak adalah saat konflik di antara tokoh-tokohnya sedang mengalami penaikan. Peleraian adalah tahap konflik mulai surut dan alur mulai terungkap, dan tahap akhir yaitu penyelesaian semua konflik yang terjadi dalam cerita.

Dalam alur juga terdapat istilah pengaluran. Pengaluran adalah teknik atau cara-cara menampilkan alur. Penyampaian alur dibagi menjadi 3 yaitu, alur maju, mundur, dan campuran. Alur maju atau lurus adalah alur yang melukiskan peristiwa-peristiwa yang berurutan dari awal sampai akhir cerita. Alur mundur adalah alur yang menggambarkan cerita secara flashback atau dari akhir ke awal cerita. Sementara alur campuran adalah alur yang menggambarkan cerita secara acak. Dalam lima cerita rakyat Kabupaten Purbalingga yang dianalisis, keseluruhan menggunakan alur maju yang semua peristiwanya digambarkan secara urut.

\section{Latar atau Setting}

Nurgiyantoro

(2012:216)

mengemukakan bahwa latar atau setting adalah landas tumpu yang mengacu pada pengertian tempat, hubungan waktu, dan lingkungan sosial tempat terjadinya peristiwa-peristiwa yang diceritakan. Nurgiyantoro (2012:227) juga mengemukakan bahwa latar atau setting dibagi menjadi latar tempat, latar waktu, dan latar sosial. Latar tempat adalah latar yang berhubungan dengan lokasi kejadian yang diceritakan dalam karya sastra. Latar waktu adalah latar yang berhubungan dengan kapan peristiwa tersebut berlangsung. Dalam cerita rakyat Kabupaten Purbalingga, latar yang mendominasi adalah latar sosial. Latar sosial adalah latar yang berkaitan dengan perilaku kehidupan sosial masyarakat yang diceritakan dalam suatu karya sastra. Misalnya, kebiasaan hidup, adat istiadat, tradisi, keyakinan, pandangan hidup, cara berpikir, dan cara bersikap. Dapat dikatakan bahwa latar sosial merupakan lukisan status yang menunjukan hakikat seseorang atau beberapa tokoh dalam masyarakat yang ada di sekelilingnya.

\section{Amanat}

Amanat adalah pesan yang akan disampaikan melalui cerita. Amanat juga disebut sebagai hikmah dalam permasalahan hidup yang terjadi dalam cerita. Melalui amanat, penulis cerita ingin menyampaikan sesuatu yang positif yang dapat diterapkan dalam kehidupan. Nurgiyantoro (2012:336) menjelaskan bahwa dalam karya sastra sering ditemukan ada pesan tersembunyi yang ingin disampaikan, tapi ada juga yang sengaja ditampilkan atau ditonjolkan. Bentuk penyampain pesan moral langsung identik dengan cara pelukisan watak tokoh yang bersifat uraian atau penjelasan.

Dalam cerita rakyat Kabupaten Purbalingga, amanat yang disampaikan secara garis besar merupakan amanat tersirat yang disembunyikan dibalik tokoh, kejadian, dan peristiwa yang terjadi dalam 
cerita rakyat. Pembaca harus menemukan sendiri pesan tersirat yang berusaha disampaikan penulis dalam cerita. Selain itu, nilai-nilai yang dalam cerita rakyat juga disampaikan secara tersirat melalui kejadian yang dialami oleh tokoh.

\section{Nilai-Nilai Peduli Sosial dalam Cerita} Rakyat Kabupaten Purbalingga

Nilai peduli sosial yang ditemukan dalam setiap cerita rakyat Kabupaten Purbalingga menunjukan bahwa dalam cerita rakyat Kabupaten Purbalingga terdapat nilai-nilai luhur yang mengajarkan pada kebaikan dan dapat digunakan sebagai bekal dalam kehidupan bermasyarakat. Ajaran tentang kebaikan ini dapat diambil melalui tokoh-tokoh yang ada dalam cerita rakyat dan melalui peristiwa-peristiwa yang diceritakan. Ajaran moral tentang kebaikan dalam cerita rakyat tersebut dapat disampaikan untuk memberikan keteladanan bagi para pembaca, generasi muda, masyarakat, dan para siswa yang berada dalam lembaga pendidikan.

Nilai peduli sosial yang ditemukan dalam kelima cerita rakyat Kabupaten Purbalingga mencerminkan pandangan hidup yang berkaitan dengan nilai-nilai kebenaran. Nilai peduli sosial ini dapat ditemukan dalam setiap peristiwa yang diceritakan dari awal sampai akhir cerita dalam cerita rakyat Kabupaten Purbalingga. Ditemukannya nilai peduli sosial yang terdapat dalam cerita rakyat Kabupaten Purbalingga ini menunjukan bahwa dalam cerita rakyat Kabupaten Purbalingga terdapat nilai-nilai positif yang berisi ajaran untuk peduli kepada sesama Nilai-nilai peduli sosial yang terdapat dalam lima cerita rakyat Kabupaten Purbalingga tersebut adalah sebagai berikut:

\section{Empati}

Empati merupakan proses memahami perasaan orang lain dan ikut merasakan apa yang orang lain alami. Empati tidak hanya sebatas memasuki dan merasakan apa yang dialami orang lain, tetapi empati yang dimiliki sesorang akan membuatnya mencoba melakukan dan menunjukan kepeduliannya. Bukti-bukti dalam cerita rakyat Kabupaten Purbalingga yang menunjukan rasa empati adalah:

Dalam cerita rakyat Asal Usul Purbalingga, perilaku empati ditunjukkan oleh Kiai Arsantaka yang turut serta dalam perang Jenar yang merupakan bagian dari perang Mangkubumen untuk membela kerajaannya yang tidak mau tunduk pada Belanda. Hal ini menunjukkan rasa kepedulian Kiai Arsantaka terhadap rakyat dan orang-orang di sekitarnya agar tidak diperalat oleh Belanda.

Dalam cerita rakyat Asal Usul Desa Selakambang, perilaku empati ditunjukkan pada saat Eyang Adi Menggala dan Eyang Purwasuci merasakan penderitaan rakyatnya yang mengeluhkan tentang perebutan wilayah Desa Selakambang dan Desa Pagerandong yang tidak kunjung menemukan penyelesaian masalah. Perilaku empati juga ditunjukkan oleh Eyang Purwasuci dan Eyang Adi Menggala ketika merasakan penderitaan rakyat yang mengeluhkan tentang sempitnya wilayah yang mereka tinggali saat ini.

Dalam cerita rakyat Asal Usul Desa Siwarak, perilaku empati ditunjukkan oleh Akhmad dan Mohamad yaitu ketika Akhmad dan Mohamad melihat masyarakat sekitar dipaksa memeluk keyakinan yang dianut oleh kerajaan Majapahit. Akhmad dan Mohamad tidak tinggal diam, sebab masyarakat merasa tidak nyaman apabila semua hukum kerajaan harus ditaati termasuk dalam memeluk keyakinan. Akmad dan Mohamad juga turut merasakan penderitaan rakyat yang dipaksa memeluk keyakinan dari kerajaan. Perilaku empati juga ditunjukkan ketika Bangas dan Bangis yaitu pengikut Akhmad dan Mohamad turut merasakan penderitaan Akhmad dan Mohammad dalam menyebarkan agama Islam yang diancam akan dibunuh oleh seorang senopati bernama Ki Sutaraga. 


Dalam cerita Legenda Kerajaan
Jambu Karang, perilaku empati
ditunjukkan ketika Pangeran Jambu
Karang melakukan perjalanan untuk
mencari sebuah nur atau cahaya yang
dilihatnya di sebelah puncak Gunung
Karang bersama 160 pengikutnya, dan
merasakan beban pengikutnya yang
merupakan rakyat biasa selama
perjalananan tersebut berlangsung. Selain
itu, perilaku empati juga ditunjukkan oleh
Pangeran Jambu Karang ketika Pangeran
Jambu Karang lebih memilih untuk
berkelana dan melihat keadaan rakyatnya
daripada diangkat menjadi raja untuk
menggantikan ayahnya, Prabu Brawijaya
Mahesa Tandreman.
Dalam cerita rakyat Legenda
Pedukuhan Cibuek, perilaku empati
ditunjukkan oleh Ki Gede Buara dan Nyi
Gede Buara yang dengan ikhlas
menampung pemuda miskin sebatang kara
yang meminta pertolongan kepada mereka
berdua. Tanpa sepengetahuan Ki Gede
Buara dan Nyi Gede Buara, pemuda
tersebut sebenarnya adalah Raden Jaka
Katuhu yang diutus oleh Raja Baribin
untuk mengabdikan diri kepada rakyat
sebelum diangkat menajdi raja agar
mengetahui betapa sulitnya kehidupan
rakyat yang kelak akan dipimpinnya.
Perilaku empati juga dicontohkan oleh
Raja Baribin yang sudah terlebih dahulu
mengabdikan diri kepada rakyat sebelum
dirinya menjadi raja dan memimpin
rakyatnya. Hal ini dimaksudkan agar raja
yang memimpin dapat lebih bijaksana
dalam mengambil keputusan dan tidak
semena-mena kepada rakyat.

\section{Saling Mengasihi}

Perlaku saling mengasihi adalah sikap untuk saling menghormati dan mengasihi semua ciptaan Tuhan berlandaskan hati nurani yang luhur. Kasih sayang dapat diterapkan di keluarga, masyarakat, kehidupan sehari-hari, dan dimanapun yang merupakan bagian dari lingkungan sosial. Berikut ini merupakan perilaku saling mengasihi yang terdapat dalam cerita rakyat Kabupaten

Purbalingga:

Dalam cerita rakyat Asal Usul Purbalingga perilaku saling mengasihi ditujukkan pada saat Kiai Arsayudha putra dari Kiai Arsantaka, menerima saran dari ayahnya untuk berkelana ke arah selatan. Perjalanan tersebut dimaksudkan untuk melihat keadaan rakyat yang ada di daerah sekitar Masaran dan mencari wilayah yang cocok dijadikan sebagai pusat pemerintahan.

Dalam cerita rakyat Asal Usul Selakambang, Eyang Purwasuci menunjukan sifat kepeduliannya dengan tidak membalas perbuatan Eyang Adi Menggala yang telah mengirimkan hujan batu di wilayah Desa Selamanik. Eyang Purwasuci lebih memilih menghalau batubatu besar kiriman dari Eyang Adi Menggala dan tidak membalas serangan Eyang Adi Menggala.

Dalam cerita Asal Usul Desa Siwarak, perilaku saling mengasihi ditunjukkan ketika Akhmad dan Mohamad melindungi satu sama lain dengan cara bertarung melawan prajurit Ki Sutaraga agar mereka berdua selamat. Akhmad dan Mohamad melakukan berbagai cara dan berbagai strategi untuk saling melindungi dan menghindari kejaran seorang senopati bernama $\mathrm{Ki}$ Sutaraga yang ingin membunuh mereka berdua.

Dalam cerita Legenda Kerajaan Jambu Karang, perilaku saling mengasihi ditunjukkan oleh Pangeran Atas Angin yang berusaha berbaik hati kepada Pangeran Jambu Karang walaupun niat baiknya tersebut dibalas dengan ajakan berduel oleh Pangeran Jambu Karang. Selepas berduel dan mengalahkan Pangeran Jambu Karang, Pangeran Atas Angin tetap menasihati Pangeran Jambu Karang dan membagikan perjalanan spiritualnya kepada Pangeran Jambu Karang yang saat itu goyah dengan keyakinannya yang membuat Pangeran Jambu Karang mantap masuk Islam dan bergelar Syekh Pangeran Jambu Karang. 
Dalam cerita rakyat Legenda Pedukuhan Cibuek, perilaku saling mengasihi ditunjukkan oleh Raja Baribin kepada putranya yaitu Raden Jaka Katuhu yang hendak diangkat menjadi raja. Raja Baribin memberikan wejangan kepada Jaka Katuhu agar selalu memahami rakyatnya dan tidak berlaku semena-mena kepada rakyat yang berada dalam pimpinannya. Perilaku saling mengasihi juga ditunjukkan oleh Raden Jaka Katuhu kepada rakyatnya. Raden Jaka Katuhu rela mengabdikan diri kepada rakyat tanpa menunjukan jati dirinya agar rakyat tidak membedakan perlakuan dan menganggap dirinya istimewa. Selain itu, perilaku saling mengasihi juga ditunjukkan oleh $\mathrm{Ki}$ Gede Buara dan Nyi Gede Buara yang mau menampung Raden Jaka Katuhu di rumahnya yang pada saat itu menyamar menjadi pemuda sebatang kara. Mereka menampung Raden Jaka Katuhu tanpa pamrih dan menganggapnya seperti anak kandung mereka sendiri.

\section{Membangun Hubungan Baik}

Perilaku membangun hubungan baik adalah menjaga hubungan dengan sesama yang berlandaskan pada komunikasi dan interaksi yang baik untuk diterapkan dalam kehidupan sehari-hari. Membangun hubungan baik sangat penting dilakukan untuk memiliki berbagai macam hubungan dengan orang lain yang sifatnya permanen. Berikut ini merupakan contoh perilaku membangun hubungan baik yang terdapat dalam cerita rakyat Kabupaten Purbalingga:

Dalam cerita rakyat Asal Usul Purbalingga membangun hubungan baik ditunjukkan oleh Kiai arsantaka yang dengan patuh menuruti perintah dari Raja untuk melakukan pengelanaan dan terjun langsung untuk melihat keadaan rakyatnya agar para rakyatnya dapat menyampaikan keluh kesahnya.

Dalam cerita Asal Usul Desa Selakambang, perilaku membangun hubungan baik ditunjukkan oleh Eyang Adi Menggala dengan lebih memilih mengalah dan mengurungkan niatnya untuk memperluas wilayah Desa Pagerandong sampai mengambil sebagian wilayah Desa Selamanik, agar masalah tidak bertambah panjang. Perilaku membangun hubungan baik juga ditunjukkan oleh masyarakat Desa Pagerandong dan Desa Selamanik yang meilih untuk saling berdamai daripada membuat permasalahn menjadi bertambah panjang karena adanya dampak dari perebutan wilayah.

Dalam cerita Asal Usul Desa Siwarak, perilaku membangun hubungan baik ditunjukkan ketika Akhamd dan Mohamad melakukan pengembaraan untuk semakin memperluas penyebaran agama Islam hingga ke pelosok desa-desa di lereng Gunung Slame. Pengembaraan ini bertujuan untuk membangun interaksi yang baik dengan masyarakat sekitar. Akhmad dan Mohamad juga turut serta masuk dalam kehidupan masyarakat biasa untuk menyebarkan agama Islam agar tujuan dari penyebaran agama Islam tersebut dapat berjalan dengan baik.

Dalam cerita LegendaKerajaan Jambu Karang, perilaku membangun hubungan baik ditunjukkan ketika Pangeran Atas Angin berusaha menyapa Pangeran Jambu Karang dengan baik walaupun sebelumnya belum mengenalnya. Selain itu, Pangeran Atas Angin juga berusaha untuk menghindari ajakan duel dari Pangeran Jambu Karang agar tidak terjadi permasalahan yang berbuntut panjang. Perilaku membangun hubungan baik juga ditunjukkan oleh para pengikut Pangeran Jambu Karang yang berusaha membangun hubungan baik dengan para pengikut Pangeran Atas Angin setelah duel tersebut terjadi di anatara Pangeran Jambu Karang dan Pangeran Atas Angin.

Dalam cerita Legenda Pedukuhan Cibuek, perilaku membangun hubungan baik ditunjukkan oleh Raden Jaka Katuhu yang tidak membuka jati dirinya pada saat mengabdikan diri kepada masyarakat agar masyarakat tidak memperlakukan Raden 
Jaka Katuhu sebagai seorang putra mahkota. Raden Jaka Katuhu ingin mengakrabi dan masuk ke dalam kehidupan rakyatnya agar pada saat menjadi raja, Raden Jaka Katuhu dapat mengambil berbagai macam kebijakan tanpa membebani rakyatnya.

\section{Relevansi Cerita Rakyat sebagai Pengembangan Pendidikan Karakter dan Bahan Ajar di Sekolah Menengah Pertama (SMP)}

Relevansi nilai kepedulian sosial sebagai pengembangan pendidikan karakter dalam pembelajaran bahasa Indonesia diterapkan dengan cara mengombinasikan cerita rakyat dengan pembiasaan perilaku siswa dan memberikan bahan ajar yang dapat digunakan sebagai media untuk mengembangkan karakter siswa. Hal ini dapat diterapkan untuk mengembangkan karakter siswa khususnya dalam mata pelajaran Bahasa Indonesia apabila dapat diterapkan dengan baik. Hal pertama yang harus dilakukan untuk menerapkan nilai kepedulian sosial kepada siswa adalah, guru mengintegrasikan aspek keteladanan pada nilai kepedulian sosial di dalam maupun di luar kegiatan belajar mengajar.

Relevansi cerita rakyat sebagai media pembelajaran dan pengembangan pendidikan karakter diterapkan pada kelas VII semester 1 dalam KD 3.4 dan 4.4 pada materi fabel dan puisi rakyat. Kompetensi dasar dan indikator pencapaian kompetensi pada KD 3.4 adalah menelaah struktur dan kebahasaan teks narasi (cerita fantasi) yang dibaca dan didengar. Indikator pencapaian KD 3.4 adalah merinci struktur cerita fantasi, menyimpulkan karakteristik bagian-bagian cerita fantasi, menelaah hasil melengkapi cerita fantasi dari segi struktur cerita fantasi, memperbaiki diksi cerita fantasi, dan mengomentari cerita fantasi. Kompetensi dasar dan indikator KD 4.4 adalah menyajikan gagasan kreatif dalam bentuk cerita fantasi secara lisan dan tulis dengan memperhatikan struktur dan penggunaan bahasa. Indikator pada KD 4.4 adalah merencanakan pengembangan cerita fantasi, menulis cerita fantasi dengan memperhatikan pilihan kata, kelengkapan struktur, dan kaidah penggunaan kata/kalimat/tanda baca/ejaan. Dalam penelitian ini, pemanfaatan nilai peduli sosial diterapkan dalam pembelajaran Bahasa Indonesia kelas VII semester 1.

Pada penelitian yang dilakukan di kelas VIIB dapat terlihat ketika guru menerangkan fabel dan puisi rakyat. Siswa kemudian diharuskan menganalisis unsur intrinsik dan ekstrinsik yang terdapat dalam fabel. Siswa dapat menganalisis unsur intrinsik dan ekstrinsik fabel secara kelompok dan mempresentasikannya. Hal ini menunjukan bahwa cerita dapat menjadi media pembelajaran yang efektif dan dapat meningkatkan kepekaan peserta didik tentang nilai-nilai yang terdapat di dalam cerita tersebut. Dalam tahapan menganalisis cerita rakyat peserta didik diajak berpikir tentang segala kemungkinan yang akan timbul sehubungan dengan tanggapannya mengenai cerita rakyat. Peserta didik dapat menganalisis cerita rakyat dan unsur-unsur yang termuat serta memberikan tanggapan tentang cerita rakyat ketika peserta didik telah menguasai materi.

Penguasaan materi peserta didik didapatkan ketika peserta didik meningkatkan kebiasaan membaca dengan menjadikan cerita rakyat sebagai bahan ajar Bahasa Indonesia. Guru perlu menjaga agar peserta didik dapat menjelaskan argumennya secara terbuka serta dapat saling menghargai pendapat ketika peserta didik mempresentasikan hasil diskusinya tentang cerita rakyat. Upaya ini dimaksudkan agar perbedaan pendapat tumbuh dengan baik. Hal ini membuktikan bahwa cerita rakyat dapat digunakan sebagai pengembangan karakter peserta didik dengan menghargai pendapat orang lain, sekaligus media meyampaikna pesanpesan moral yang di dalamnya terdapat nilai peduli sosial yang dapat digunakan sebagai bahan pembelajaran Bahasa Indonesia. 
Pembelajaran sebagaimana dalam konsep aslinya yaitu dengan membawa peserta didik masuk dan berhadapan dengan masalah sosial. Masalah sosial adalah situasi sosial yang mengandung konflik moral sehingga memungkinkan peserta didik masuk dalam arus situasi yang mengharuskan peserta didik melakukan pertimbangan moral untuk mengambil sebuah keputusan. Reaksi peserta didik dalam pembelajaran merupakan ekspresi kesadaran moralnya yang konsisten, karena dihadapkan pada persoalan yang nyata. Kondisi ini akan mendorong peserta didik memberikan tanggapan serta tindakan yang seharusnya dilakukan sesuai dengan tingkat pemahaman dan penghayatannya terhadap materi yang diajarkan .

Pembelajaran yang baik dan sistematis membutuhkan bahan ajar yang sesuai dengan materi pembelajaran yang sedang berlangsung. Materi pembelajaran yang dikombinasikan dengan bahan ajar yang tepat akan berdampak pada pemahaman siswa dengan materi yang diajarkan oleh guru. Materi cerita rakyat, fabel, dan puisi rakyat yang diajarkan oleh guru di kelas VII, VIII, IX dikombinasikan dengan nilai pendidikan karakter yang memuat nilai-nilai peduli sosial. Nilainilai peduli sosial dalam cerita rakyat dapat dijadikan sebagai bahan ajar Bahasa Indonesia di Sekolah Menengah Pertama (SMP) dengan cara menerapkan nilai-nilai tersebut dalam materi-materi pembelajaran Bahasa Indonesia yang sedang berlangsung. Cerita rakyat yang memuat nilai-nilai peduli sosial dapat menjadi bahan ajar yang lebih efektif untuk materi pembelajaran Bahasa Indonesia karena peserta didik secara langsung dapat lebih berorientasi pada upaya untuk melatih kepekaan perasaan dan perhatiannya dengan menghadapkan peserta didik pada masalah representative yang terdapat dalam cerita rakyat, sehingga selanjutnya peserta didik dapat dapat lebih menghayati materi pembelajaran secara mendalam, untuk kemudian menggerakan pemikiran, perasaan, dan tindakan yang harus dihadapi dalam suatu pembelajaran dan membentuk karakter siswa.

\section{SIMPULAN}

Berdasarkan hasil penelitian dan pembahasan yang telah diuraikan di atas, dapat ditarik tiga simpulan. Pertama, dalam penelitian ini terdapat 5 cerita rakyat yang dikaji yaitu Asal Usul Purbalingga, Asal Usul Desa Selakambang, Asal Usul Desa Siwarak, Legenda Kerajaan Jambukarang, dan Legenda Pedukuhan Cibuek. Struktur cerita rakyat Kabupaten Purbalingga tersebut sebagian besar berisi dan bertema asal usul suatu tempat dan perjuangan seorang tokoh dalam memperjuangkan kebenaran. Alur cerita yang digunakan adalah alur maju yang bersifat sederhana dan hanya ada sedikit percakapan sehingga jalan cerita dari awal sampai akhir mudah dipahami. Tokoh kunci dalam cerita rakyat Kabupaten Purbalingga tersebut adalah manusia yang digambarkan memiliki kelebihan tertentu dan berkarakter baik. Dalam cerita rakyat Kabupaten Purbalingga, yang paling ditonjolkan adalah latar tempat yang mendominasi lima cerita rakyat. Amanat dan nilai-nilai peduli sosial yang terkandung dalam cerita rakyat Kabupaten Purbalingga juga bervariasi yang disisipkan melalui tokoh sentral pada masing-masing cerita.

Kedua, nilai-nilai peduli sosial yang terkandung dalam cerita rakyat Kabupaten Purbalingga dapat menjadi pendukung pembentukan karakter siswa Sekolah Menengah Pertama (SMP) yang direalisasikan melalui kegiatan sehari-hari dan sebagai bahan ajar Bahasa Indonesia. Nilai-nilai peduli sosial yang terdapat dalam cerita rakyat Kabupaten Purbalingga adalah rasa empati, saling mengasihi, dan membangun hubungan baik dengan sesama.

Ketiga, relevansi cerita rakyat sebagai pengembangan karakter siswa dapat digunakan untuk menanamkan kepribadian kepada siswa melalui nilai- 
nilai yang terkandung dalam cerita rakyat. Sedangkan sebagai bahan ajar, cerita rakyat dapat digunakan sebagai media pembelajaran Bahasa Indonesia. Siswa dapat diarahkan untuk menganalisis cerita rakyat yang meliputi unsur intrinsik dan unsur ekstrinsik. Hal ini dapat dijadikan

\section{REFERENSI}

Benninga, J.S., Berkowitz Marvin W., Kuehn Phyllis., Smith Karen. (2003).

The Relationship of Character Education Implementation and Academic Achievement In Elementary Schools. Journal of Research in CharacterEducation 1(1), 2003, pp. 19-32.

Burhan, Nurgiyantoro. (2002). Teori Pengkajian Fiksi. Yogyakarta: Gadjah Mada University Press.

Danandjaja, James. (1997). Folklor Indonesia: Ilmu Gosip, Dongeng, dan lain-lain. Jakarta: Grafiti.

Davidson, Mathew, dkk. (2007). Smart and Good Schools. Education Week .November 2007.

Fathur, Rokhman. (2013). Character Education For Golden Generation 2045 (National Character Building for Indonesian Golden Years). ElsevierAcademic Press: California.

Hutomo, Suripan Sadi. (1991). Mutiara yang Terlupakan: Pengantar Studi Sastra Lisan. Surabaya: HISKI Jawa Timur.

Maunah, Binti. (2015). Implementasi Pendidikan Karakter dalam Pembentukan Kepribadian Holistik Siswa. Jurnal Pendidikan Karakter. Vol 1 (5).

Meliono, Irmayanti. (2011). Understanding the Nusantara Thought and Local Wisdom. International Jurnal for Historical Studies. Vol 2 (2).

Organization for Economic Co-operation and Development (OECD), Data Programme Internationale for Student Assesment (PISA) sebagai tolok ukur pemahaman siswa tentang pendalaman materi cerita rakyat. Cerita rakyat yang banyak memuat nilainilai pendidikan karakter termasuk di dalamnya nilai peduli sosial dapat melatih pembentukan karakter siswa dan meningkatkannya secara bertahap.

Soenarko, Bambang. (2015). Peningkatan Nilai Kepedulian Sosial Melalui Modifikasi Model Pembelajaran Konsiderasi Pada Mahasiswa Tingkat 1 Program Studi PGSD FKIP Universitas PGRI Kediri. Jurnal Efektor, Vol. 4 (26)

Teeuw, A. (2003). Membaca dan Menilai Sastra. Jakarta: Gramedia.

Wibowo, Agus. (2012). Pendidikan Karakter: Strategi Membangun Karakter Bangsa Berperadaban. Yogyakarta: Pustaka Pelajar. 